\title{
BUILDING INTERDISCIPLINARY RESEARCH GROUP FOR VOCATIONAL COLLEGE UNIVERSITAS GADJAH MADA
}

\author{
Indah Novita Sari ${ }^{1 *}$, Ahmad Mu'am ${ }^{1}$ \\ ${ }^{1}$ Universitas Gadjah Mada \\ Jl. Persatuan, Blimbing Sari, Caturtunggal, Depok, Sleman, Yogyakarta 55281, Indonesia
}

\begin{abstract}
This research aimed to form a collaborative research and research group in the Department of Languages, Arts and Culture Management, Vocational College of Universitas Gadjah Mada (Departemen Bahasa, Seni, dan Manajemen Budaya or DBSMB). This research is essential for considering DBSMB's needs in developing applied products as a result of interdisciplinary research. On a broader scale, vocational education institutions outside UGM can see an overview of the multidisciplinary research process that has been carried out. The research group was formed in the Culture and Tourism Center, which was based on a functional perspective of organizational functions. The exploratory method was carried out by observation, interview, and literature study. Interviews were conducted with informants consisting of the head of the Teaching Industry Learning Center (TILC), head of study programs, secretary of study programs, and lecturers at DBSMB. The results showed that each lecturer at DBSMB had different research interests. Lecturers' research interests had several intersections that could be made into collaborative research groups. The central theme of culture and tourism could accommodate research collaborations from lecturers in the study programs of Record Management, English, Tourism, Korean Language, and Japanese Language. The challenges in the formation of the research group came from internal factors (communication, funding, and infrastructure) and external factor (collaboration with industry, policy differences, administrative procedures, and interests in research). This research was expected to contribute to the formation of a research group in other vocational education institutions and affect the improvement of vocational graduates' quality and scientific development.
\end{abstract}

Keywords: research group, collaboration, vocational education

How to cite: Sari, I., \& Mu'am, A. (2020). Building interdisciplinary research group for Vocational College Universitas Gadjah Mada. Jurnal Pendidikan Vokasi, 10(3), 249-259. doi:https://doi.org/10.21831/jpv.v10i3.32099

*Corresponding Author: Indah Novita Sari @ indah.novita.s@mail.ugm.ac.id

- Department of Languages, Arts and Culture Management, Vocational College, Universitas Gadjah Mada

Jl. Persatuan, Blimbing Sari, Caturtunggal, Depok, Sleman, Yogyakarta 55281, Indonesia 


\section{INTRODUCTION}

Education and capacity building for human resources always become an issue to be discussed in Indonesia. One of the issues is vocational education, which is expected to meet the increaseingly diverse needs of the industry. In addition, it was stated by the President of the Republic of Indonesia (Ihsanuddin, 2019) that vocational education and training must be improved so that they can identify their goals. The arising problem of vocational education is how to adjust (link and match) with the industrial world. Triyono $(2017$, p. 2) explained that vocational education must adjust to the work field's needs, which leads to a more flexible vocational education, which can adapt quickly to changes.

Significant changes in vocational education are needed because of the rapid changes in industry and community demands due to developments in information technology. The work field in the recent days and the future have shown the tendency to use various digital devices; a very rapid change of both goods and services industry work field has begun with the industrial revolution 4.0 (Triyono, 2017, p. 2). Historically, the concept of industry 4.0 was first conceived by the German government (Shamim et al., 2017, p. 1), which promoted digitalization or computerization projects to increase German government revenues. Practical implications arise for vocational education, especially the availability of quality human resources who are able to adapt and have skills according to the current development. Shamim et al. $(2017$, p. 2) show that the challenges of Industry 4.0 are related to the need for continuous innovation and learning, depending on individual and organizational abilities.

More complex demand in vocational education requires serious effort, which involves various elements. Some of the efforts are by strengthening the relationship with the industries, developing sufficient infrastructure for learning activities, improving the education system, and preparing lecturers for innovative teaching and learning. Related to infrastructure, Sudira (2017) revealed that vocational education could be held in classrooms, workshops, laboratories, studios, or teaching factories. Furthermore, for bringing it closer to the real world, it looks better to have it conducted in business centers, edotels, technoparks, hospitals, clinics, fields, agriculture, livestock centers, fisheries, industrial places, work, business world, sports field, community, and so on. Provision of these learning facilities is not an easy effort but requires a struggle to improve the quality of vocational education in Indonesia.

The typical learning process is no longer relevant to vocational education. Sudira (2017) explains the concept of TVET (Technical and Vocational Education Training) that is important designed to develop the full potential of students to have work insight, work technical skills, employability skills, and carry out self-transformation towards changing demands on the new work world. Moreover, the employability skills themselves are split into five basic categories covering basic soft skills, analytical skills, digital and technical skills, core marketing skills and customer insight skills (Gregorio et al., 2019 p. 257). In a learning process, these skills are deemed crucial as they are viewed as well as the indicators for the quality of training (Espinoza et al., 2020, p. 8) and as foundation of career success for someone in a long term (Blokker et al., 2019, p.182). The development of the learning process must be supported by a learning center and laboratory to meet the challenge and demand of industry 4.0. Project-based independent learning, which is carried out in a learning center, can sharpen students' skills. This innovation needs sufficient infrastructure supports and human resources as the drive. The further objective of increasing students' skills and creating products is not easily achieved. Thus, the available human resources are expected to collaborate to answer the challenge in vocational education.

Vocational College Universitas Gadjah Mada has designed infrastructure improvement and lecturer readiness based on the problems and challenges in vocational education. In the infrastructure aspect, Vocational College UGM planned the construction of TILC (Teaching Industry Learning Center) in 2018. TILC has several centers of excellence which are aimed at a learning center and to strengthen the relationship (link and match) with the industries. TILC project has broader aims to improve the graduates' quality, become a new source of financing, as well as create more students' involvement in the issues in the field. Those are in line with what should be done by higher education as explained by Sackey et al. (2017, p. 50) that educational institution is similar to 
learning factories in terms of the contextualization by providing real-world experiences to foursided wall learning space. At last, such institution are believed to be the right requirement to build $\mathrm{e}$ network between industrials and academic/research actors (Mavrikios et al., 2018, p. 5), and at some points, it brings the right learning environment needed (Mavrikios et al., 2019, p. 402) by bringing a multidisciplinary learning (Jooste et al., 2020, p. 379). Some laboratories built are essential assets for Vocational College UGM, which will be used for product and scientific development in the future.

The adequate infrastructure must be in line with the readiness of the human resources, which in this context refers to the lecturers. The lecturers are expected to suit themselves with the character of vocational education and adapt to a fast-changing environment. Some new competencies which must be mastered are teaching design, teaching and learning guidance, research on teaching content, research on teaching methods, career and interpersonal relationship guidance, management support for school and class, cooperation (Ye-weon Jeon et al. in Triyono, 2017, p. 4).

One of the critical collaborations which can be a foundation to run TILC programs is research collaboration. The research collaboration will encourage the development of knowledge and the creation of products to be used by the market. The collaboration can involve interdisciplinary studies, and in the future, it is expected to involve practitioners. On a broader scope, collaboration can also bring more benefits to answer the demand of the industries and the problems in society (Mann et al., 2020, p.447). The real-world problem's complexity cannot be solved only with one field. Thus, TILC is needed as a medium to bridge the researchers so that they can solve problems in society. It is also stated in a report by National Academies (2005, p.40) as follows.

Interdisciplinary thinking is rapidly becoming an integral feature of research as a result of four powerful "drivers." The inherent complexity of nature and society, the desire to explore problems and questions that are not confined to a single discipline, the need to solve societal problems, and the power of new technologies.

In the beginning stage, the researchers focused on the initiation of the research group in the Department of Languages, Arts and Culture Management (Departemen Bahasa, Seni, dan Manajemen Budaya or DBSMB), Vocational College of Universitas Gadjah Mada (UGM), which was a tourism and culture center. The tourism and Culture Center was designed in order to accommodate interdiscipline research for the lecturers in the department, which covered the study programs of D3/D4 Records and Archives Management, D3/D4 English, D3/D4 Tourism, D3 Korean Language, and D3 Japanese Language. The mapping of research interest and research group initiation became an essential step in designing the learning center to facilitate interdisciplinary research. Such interdisciplinary research offers much benefit for knowledge integration (Ávila-Robinson \& Sengoku, 2017, p. 40) and collaboration skills (Soto et al., 2013, p. 2154; Zuo \& Zhao, 2018, p. 745).

Stakeholders initiated the formation of a research group in the learning center being designed (TILC) at the department and faculty level. This new learning center was expected to be used to develop knowledge and products. The creation of appropriate products and skills development based on the problems in the field could be done based on collaboration. The initial problem that the researchers were trying to reveal was related to the research interests of lecturers in the scope of the DBSMB at Vocational College UGM. The design of group research could be carried out later by the department to develop a new learning center, namely the tourism and culture center. Interdisciplinary research collaboration, of course, presented specific opportunities and challenges. Understanding the opportunities and challenges of collaborative practices in the tourism and culture center could maximize opportunities and minimize undesirable things due to external challenges.

This research is expected to contribute to the planning of the teaching industry at the department level so that the Tourism and Culture Center can be used to the maximum extent possible for product and scientific development. In a broader aim, it can be used by policymakers in the academic realm to prepare human resources in the teaching industry learning center in the future. Therefore, the teaching industry learning center will be seen as infrastructure, but are filled with quality human resources from various fields of study which are appropriate to their abilities and capacities in solving problems in the field. 


\section{RESEARCH METHOD}

This research used the exploratory study approach by using a mixed research method between empirical research and development. The focus of exploratory research is to obtain ideas and understanding of a problem so further research can be carried out and more directed (Hermawan, 2014, p. 82). The research setting was carried out at the Department of Languages, Arts and Culture Management (DBSMB), Vocational College of Universitas Gadjah Mada. Lecturers' research data and road map of their research interest was used to see the compatibility between teaching industry learning center needs and interdisciplinary research. This type of research has not much developed in the education field. An exploratory approach was then chosen to answer problems that have not been much studied before (Cohen et al., 2007).

The data used in this study included primary and secondary data. The primary data needed are research interest, the needs of study programs, and the Culture and Tourism Center. The secondary data needed are the data which have been previously documented, related to the research theme.

Data collection was done by several techniques, namely observation, interviews, and literature study. In-depth interviews were done to the research informants. The selected informants were the head of Vocational College's TILC, secretary of study programs of Records and Archives Management, English, Tourism, Korean Language, and Japanese Language as well as lecturers in DBSMB. The activities were done to explore the potential of each study program, including human resources, scientific development, facilities, and infrastructure, as well as potential collaboration. After that, a mapping was created to know the needs and various competencies to support the development of a cultural and tourism center. Focus Group Discussion involved the head and secretary from five study programs in DBSMB.

\section{RESULTS AND DISCUSSION}

The research group, which was designed by the researchers of this study, was formed based on several things, namely research interest, the direction of study program development, department development flow, and the design of the Teaching Industry Learning Center (TILC). In the smallest scope, which was individuals, the researchers tried to map research interests among lecturers in each study program. At the level of study programs, a road map for developing study programs was needed to clarify skills and academic development plans and needs which needed to be accommodated. At the department and faculty level, preparation of collaboration patterns needed to be designed to prepare funding and project support. There were needed for the implementation of programs to improve the skills and academic abilities of the academic community in a vocational college.

\section{Research Map Interest}

Groups are complex and dynamic systems (Berdahl \& Henry, 2005, pp. 19-38). The initiation of a research group is not a simple work to do because it is related to building relationships among the individuals within the group. Some of the researchers had studied research group, including others Berdahl and Henry (2005), Cummings and Ancona (2005), and National Academies (2005).

National Academies (2005, p. 152) explained the factors related to the formation of the research group, which are the complexity of the existing problems in science and social studies, the need to explore the correlations of various branches of knowledge, and the need to solve social problems and stimuli to generative technology. The real-world problems can be used to bridge the collaboration of lecturers in the scope of department or vocational college.

Furthermore, Berdahl and Henry (2005) have reviewed the problems of the research group. Berdahl and Henry (2005, pp. 19-38) focused on several perspectives: psychoanalytic, social identity, communications, functional, developmental, systems, nonlinear dynamics, socioevolutionary, power conflict, and feminist perspectives. These perspectives can see several ways and methods which become the foundation of group formation. 
The psychoanalytic perspective explained that "humans are by nature 'group-ish"" and that group processes have biological bases (McLeod, Polley, and Geller in Berdahl \& Henry, 2005, pp. 19-38). This perspective sees that group formation is a natural process where each experiences the dynamics of the problem in the group.

The second perspective is social identity (Hogg et al. in Berdahl \& Henry, 2005, pp. 19-38), which is the process of group formation based on social identity. Further, it is explained by Berdahl and Henry (2005) that "this results in intercourse differentiation and intra-category assimilation." Inter-category refers to groups, whereas intra-category refers to individuals. It means that individuals adjust between goals and knowledge possessed (intra-category), so individuals need groups that can achieve them together (inter category).

The next perspective is a communication perspective that sees "how group members use symbols to construct interpretations of their group experience. It also focuses on how groups and their members are products of this symbolic activity" (Frey \& Sunwolf in Berdahl \& Henry, 2005, pp. 19-38). Therefore, language and symbols of information exchange are essential to be able to form and support groups.

Apart from the many perspectives which underlie group formation, the researchers used a functional perspective in the initiation of a research group in DBSMB. It was based on the perspective of organizational goals in group formation. It is in line with Cummings and Ancona (2005, p. 109), who tried to describe "how relevant the functional perspective is for understanding task-performing groups in organizations today." A functional perspective believes that the group will form properly according to ability, knowledge, and also the members who can work well. Conceptually, Wittenbaum et al. in Cummings and Ancona (2005, p. 107) defined the functional perspective as a normative approach to describing and predicting group performance that focuses on functions of inputs and processes. The use of functional perspectives for the research group formation focuses on organizational functions. However, it cannot ignore the right of each lecturer to conduct research based on their interests. Therefore, the designed research group still considered the research interests and expertise of lecturers in the DBSMB.

A project-based education system that is carried out in the learning center with the support of existing research groups is expected to contribute by solving complex vocational education problems. The demands for qualified products, services, and skills can be more natural to be fulfilled if the individuals within the organization collaborated with various parties. It is relevant to the statement of Kyvik and Reymert (2017, p. 950) that "... two or more people can do better work than if they work independently". Collaboration for vocational education can involve scholars, practitioners, as well as social institutions which have common interests. Further, supporting the statement, Beck et al. (2017, p. 535) stated that pitches might include (a) research interests and expertise, (b) selecting papers, slides, and tutorials, and also (c) common questions that each collaborator should answer.

Research interests and expertise of each lecturer became an essential foundation in the formation of research groups in the Culture and Tourism Center under the Department of Language, Arts and Cultural Management. Based on research interest data from 48 lecturers, the themes of lecturer interest are presented in Table 1.

Table 1. Research Themes by Lecturers and Study Programs

\begin{tabular}{cc}
\hline Study Program & Number of Lecturers and Interest \\
\hline D3 Tourism/D4 Travel Business & 13 lecturers with 28 research themes \\
D3 Archival Science/ D4 Records and Archives Management & 9 lecturers with 21 research themes \\
D3/D4 English & 17 lecturers with 31 research themes \\
D3 Korean Language & 3 lecturers with 4 research themes \\
D3 Japanese Language & 6 lecturers with 10 research themes \\
\hline
\end{tabular}

Based on the data in Table 1, in the D3 Tourism study program and D4 Travel Business, there were 28 themes of research interest from 13 lecturers. The research topics chosen were related to tourism, culture, culinary, management, and marketing. In D3 Record Management and D4 Archives and Records of Information Management, there were nine lecturers with 21 themes of re- 
search interest. The research topics were related to record management (dynamic and static), preservation of cultural collections, information security, and the use of technology in record management.

In the language cluster, there were D3 English, D4 English, D3 Korean Language, and D3 Japanese Language. Meantime, In D3 and D4 English, there were 31 themes of research interest from 17 lecturers. The topics studied include English, learning experiences, culture, tourism, and linguistics. In the D3 Korean Language study program, the chosen themes included culture, social economy, drama studies, and linguistics. The D3 Japanese Language study program was interested in the topics of culture, education linguistics, history and colonization of Japan.

The research topics of each lecturer in 5 study programs had a relationship with one another. This part of the research interest could be the basis for forming group research and fostering collaboration. Figure 1 presents research topics that could be collaborated based on the data of lecturers' research interest.

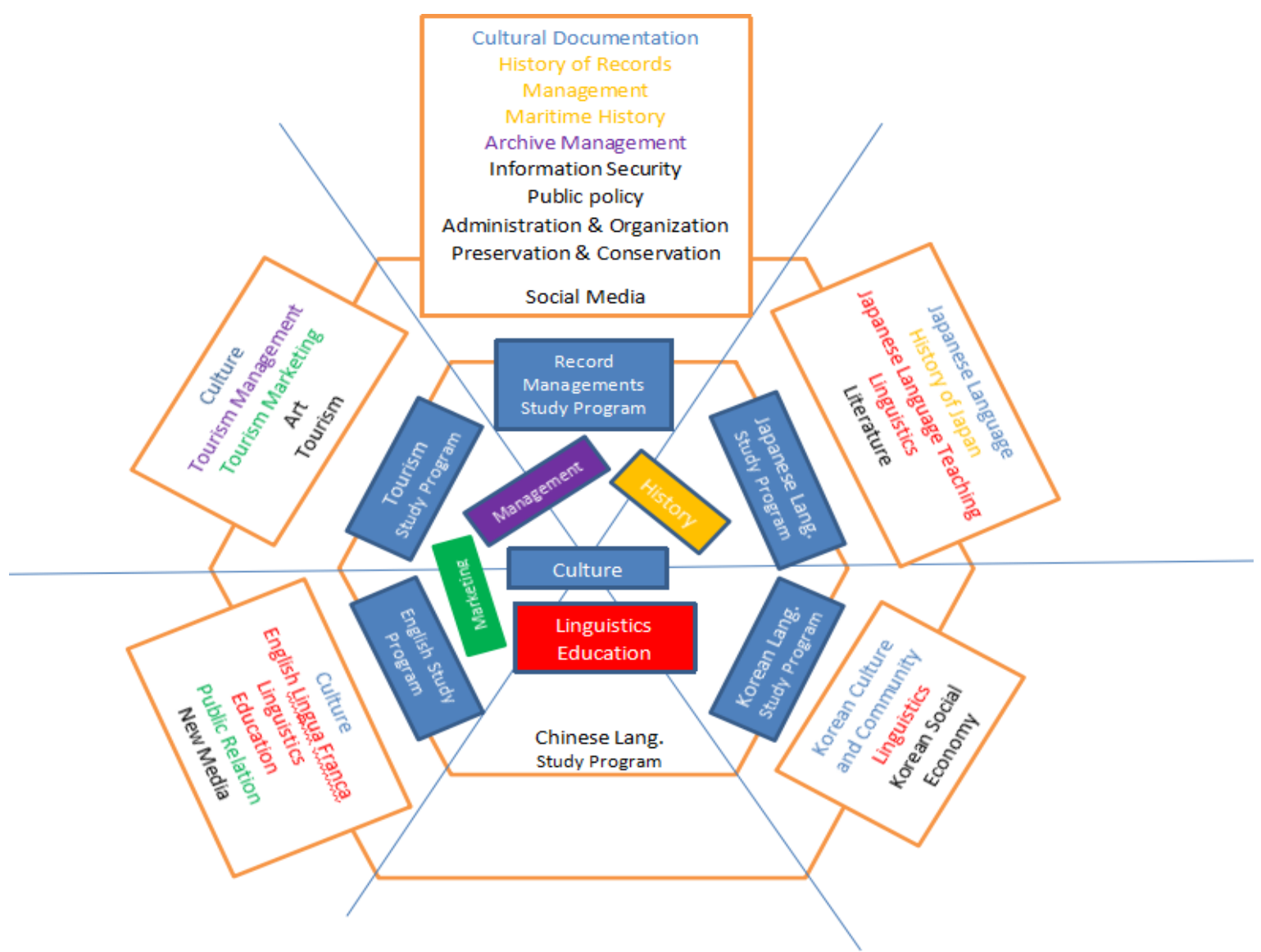

Figure 1. Potential Collaboration Based on Research Interest

Based on the potential collaboration data in Figure 1, several topics could become a collaboration between lecturers across departments. Culture-related topics (marked in blue), could be collaborated by five study programs in the department. Themes related to linguistics could collaborate between English, Korean Language, and Japanese Language study programs. There were several intersections of topics among study programs, including history, management, and marketing. Historical themes could collaborate between Japanese Language and Record Management study programs. Management topics could be carried out by Tourism and Record Management study programs. Marketing themes could collaborate between Tourism and English study programs.

Being reviewed based on the form, research collaboration could be done by lecturers across study programs as well as a research collaboration between lecturers and students. Collaborations that were carried out both vertically and horizontally were expected to be accommodated by the 
new learning center, the Culture and Tourism Center. This form of collaboration was also explained by Kyvik and Reymert (2017, p. 952) that "collaboration can be a hierarchical relationship, like the one between a professor and a doctoral student, or a mutual relationship between two or more colleagues of equal status." More detail overview of the collaboration form is shown in Figure 2.

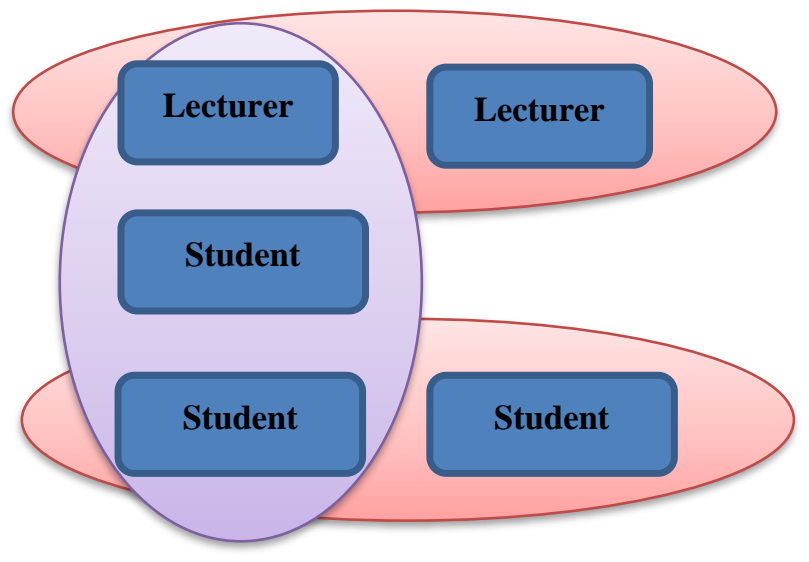

Figure 2. Form of Collaboration

Vertical and horizontal forms of collaboration related to product manufacturing projects and research projects could be a driving force for programs in the TILC's Culture and Tourism Center. Collaboration could be carried out between lecturers in research, service, and product development projects. Also, students' collaboration in doing specific tasks could be done in the teaching industry learning center. Vertical collaboration between lecturers and students could also be done to develop a branch of study.

\section{Research Group Road Map}

Internal collaboration, which was designed in Culture and Tourism Center and consisted of lecturers, students, and staff, could form a formal research group. Formal research groups have been introduced in all fields as subunits within departments (Vabo et al. in Kyvik \& Reymert, 2017, p. 953). The formal form of the research group was adjusted in the direction of the development of study programs, departments, vocational colleges, and Universitas Gadjah Mada. It was in line with the principles from a functional perspective, namely "shared goals; group composition and norms; group culture, external environment." The study programs in DBSMB has formed several research groups. Table 2 presents the research group road map in DBSMB.

Table 2. Research Map of Study Programs

\begin{tabular}{|c|c|c|c|}
\hline No & Study Programs & Research Group & Collaboration \\
\hline 1 & Tourism & $\begin{array}{l}\text { Halal tourism } \\
\text { Traditional food } \\
\text { IT of Tourism } \\
\text { Edu-Ecotourism } \\
\text { Art and Culture Commodification }\end{array}$ & $\begin{array}{l}\text { Active } \\
\text { Not yet } \\
\text { Not yet } \\
\text { Active } \\
\text { Not yet }\end{array}$ \\
\hline 2 & Records Management & $\begin{array}{l}\text { Documentation of Culture } \\
\text { IT-based Record Management }\end{array}$ & $\begin{array}{l}\text { Not yet } \\
\text { Not yet }\end{array}$ \\
\hline 3 & English & $\begin{array}{l}\text { Business communication } \\
\text { Culture Management } \\
\text { Media } \\
\text { Applied Linguistic } \\
\text { English Language Teaching }\end{array}$ & $\begin{array}{l}\text { Not yet } \\
\text { Not yet } \\
\text { Not yet } \\
\text { Not yet } \\
\text { Not yet }\end{array}$ \\
\hline 4 & Korean Language & Translation and interpreting for professional & Not yet \\
\hline 5 & Japanese Language & Language for professional/ workplace & Not yet \\
\hline
\end{tabular}

Source: Focus Group Discussion with the management of Study Programs and PPM Manager 
The research result in Table 2 shows that there were 14 research groups from five study programs. It indicated that the awareness in forming a research group for the development of knowledge had been built at the level of study programs. The problem of existing research groups was that there were only two groups that collaborated actively with other study programs, namely halal tourism and the commodification of art and culture.

Research and product development, which would be covered by the Culture and Tourism Center, were based on lecturers' research interests and the direction of study program development. Figure 3 shows the results of group research analysis which could be developed by the Culture and Tourism Center.

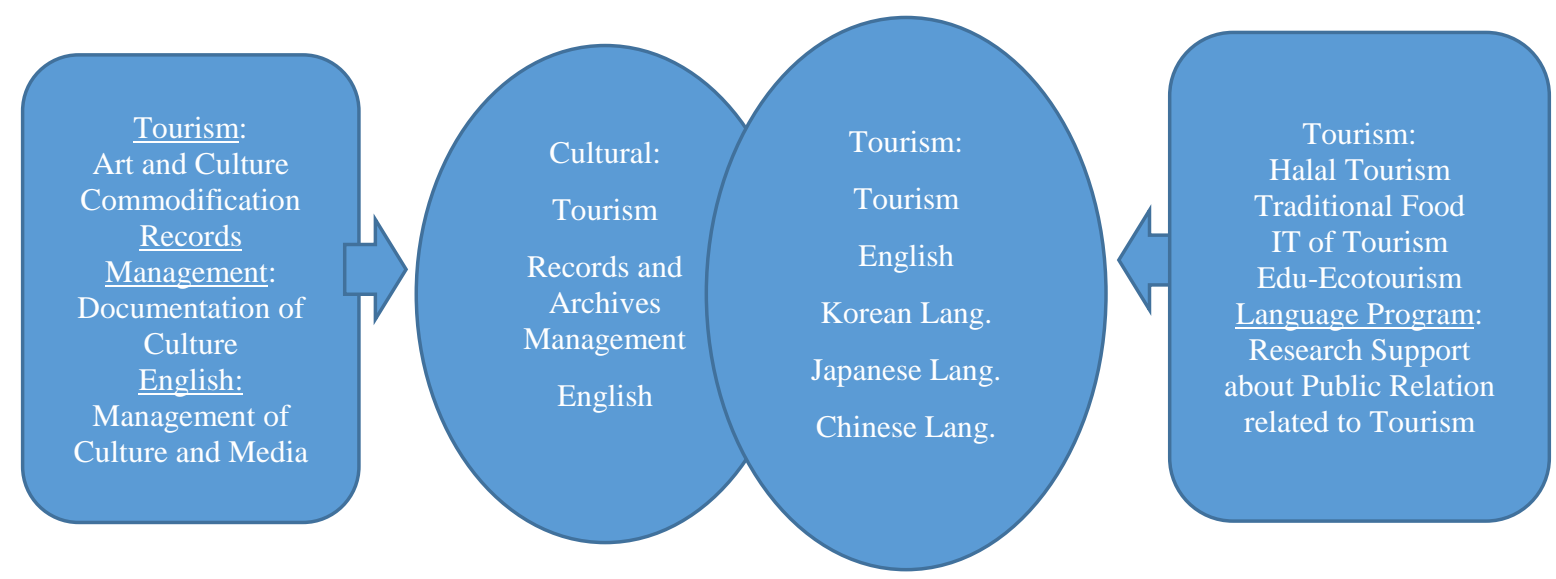

Figure 3. Research Group in Tourism and Culture Center

According to Figure 3, the research group could be divided into two major groups, namely, cultural and tourism groups, which could be developed in Culture and Tourism Center. These two groups were then supported by some study programs based on the research interest of the lecturers. The teaching industry learning center was indeed prepared to answer the demands in the fields, especially related to culture and tourism.

\section{Challenges and Opportunities for Research Group in University}

Research collaboration in vocational education had its challenges and opportunities. It could be seen from the internal and external aspects of the university. From a subjective aspect, the challenges came from creating excellent communication to support group work, infrastructure; as well as funding and facilities. The challenges came from building collaborative research with the industries, differences in policies, administrative procedures, and research interest from the external aspect.

The first internal challenge was related to the flow of communication. It was undeniable that differences in scientific backgrounds, and perspectives in the use of theory as well as methodology often caused problems in internal groups. Therefore, Beck et al. (2017, pp. 540-541) suggested functional interactions at the beginning and during research collaboration in order to help to improve the quality of understanding among each member of the study group.

Second, related to the availability of facilities, infrastructure, and funding in the research group, Vocational College of UGM tried to build a new teaching industry learning center that would be used for interdisciplinary research. It is a significant step to facilitate research activities. However, the construction of facilities and infrastructure must ideally be adjusted to the needs of the research group in it. In addition, future sources and funding mechanisms must also be formulated. It is caused by research needs and rewards for researchers (National Academies, 2005, p. $105)$.

The next challenge came from the outer side, which was building collaboration with external parties (both universities and industries). It is vital for future development because interdisciplinary research will involve many professionals, including practitioners, scientists, and people from the social organization. Figure 4 is a description of collaboration that can be built with external parties. 


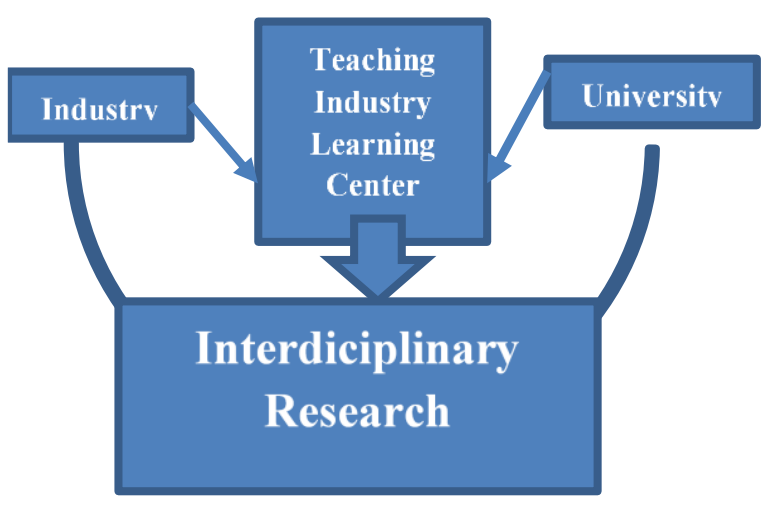

Figure 4. Collaboration with Industries in the Future

Figure 4 showed the collaboration, which can be developed with the industries in the future. In the future, the industries can assist universities in funding as well as provide facilities and infrastructure. Along with the current opportunities, the next challenges were differences in bureaucracy, policies, and interests between lecturers and practitioners in the industries. It is in line with National Academies (2005, pp. 88-89) that cultural differences - a set of customs, shared values, understandings, and relationships that develop discipline or unit - slow the communication and cooperation underlie interdisciplinary research. Although collaboration between lecturers and industry practitioners could be done, the perspective of their interests may differ. Lecturers were more focus on academics (teaching to produce publications), while industry practitioners adjusted to the need of their organizations, which was product development to make a profit.

\section{CONCLUSION}

Teaching Industry Learning Center was a project developed by the vocational college based on the movements of each research group to collaborate with agencies and industries outside the university actively. The Department of Language, Arts formed the group research initiative, and Cultural Management to support the faculty and university's vision and mission (functional perspective). Although it focused on the interests of the vocational college, the researcher could not ignore each lecturer's research interests, who would be a vital driving force in the collaboration (with students, fellow lecturers, and industry practitioners). Each lecturer in the department has different research interests but had an intersection of similarities between several themes. The similarity of themes that could be collaborated was based on interviews and data collection from 48 lecturers in the Department of Language, Arts, and Cultural Management.

It was not easy to formally established a research group because the formation must be adjusted to the research interests of lecturers (at the individual level), the direction of the development of study programs, faculties, and universities (at the institutional level) to the interests of the wider community. Therefore, the Culture and Tourism Center was expected to accommodate researchers following market needs. Cultural themes, including the commodification of art and culture, cultural documentation, and cultural and media management, could collaborate among researchers in Records Management, Tourism, and English study programs. In addition, research themes related to tourism can be collaborated by researchers from Tourism, English, Korean Language, and Japanese Language study programs

Research groups that have been proposed at the department level surely had their challenges in its management. The internal challenge was how to make existing research groups work well in the future. Therefore, it required proper management, which involved research groups (communication management) and institutions (facilities, infrastructure, and funding). The external challenge was how to embrace external parties (including industry) to collaborate with universities. Later challenges would come later related to differences in policies, administrative procedures, and research interests. However, industrial involvement could create opportunities in producing joint products, providing infrastructure, and learning experiences for the academic community. 
Through this research, the researchers tried to initiate a research group at the department level, which will be used later to develop a culture and tourism center. As an initial effort, further research is needed to be related to research groups in other departments and faculties at the university and mapping collaboration with industry. In addition to the things used for research development, several things related to the budget, the fulfillment of facilities to the clarity of mechanisms, and administrative processes need to be better designed. It is expected that existing research groups can be empowered to carry out applied research and will not encounter significant technical obstacles.

\section{ACKNOWLEDGMENTS}

This research has been funded by Vocational College UGM in Competition Research Fund, stated in Decree of Dean No. 87/UN1.SV/SK/2018. The researchers' gratitude was delivered for the opportunity and funding given to support this research.

\section{REFERENCES}

Ávila-Robinson, A., \& Sengoku, S. (2017). Multilevel exploration of the realities of interdisciplinary research centers for the management of knowledge integration. Technovation, 62-63, 22-41. https://doi.org/10.1016/j.technovation.2017.01.003

Beck, S. J., Meinecke, A. L., Matsuyama, Y., \& Lee, C. (2017). Initiating and maintaining collaborations and facilitating understanding in interdisciplinary group research. Small Group Research, 48(5), 532-543. https://doi.org/10.1177/1046496417721746

Berdahl, J. L., \& Henry, K. B. (2005). Contempory issues in group research: The need for integrative theory. In S. A. Wheelan (Ed.), The handbook of group research and practice (pp. 19-38). Sage Publication.

Blokker, R., Akkermans, J., Tims, M., Jansen, P., \& Khapova, S. (2019). Building a sustainable start: The role of career competencies, career success, and career shocks in young professional's employability. Journal of Vocational Behavior, 112, 172-184. https://doi.org/ 10.1016/j.jvb.2019.02.013

Cohen, L., Manion, L., \& Morrision, K. R. B. (2007). Research methods in education (6th ed.). Routledge.

Cummings, J. N., \& Ancona, D. G. (2005). Theoretical perspectives on groups: The functional perspective. In S. A. Wheelan (Ed.), The handbook of group research and practice (pp. 107118). Sage Publication.

Espinoza, O., Gonzales, L. E., McGin, N., Sandoval, L., \& Castillo, D. (2020). Should universities train teachers for employability or for effectiveness. Teaching and Teacher Education, 88, 102960. https://doi.org/10.1016/j.tate.2019.102960

Gregorio, A., Maggioni, I., Mauri, C., \& Mazzuccheli, A. (2019). Employability skills for future marketing professional. European Management Journal, 37, 251-258. https://doi.org/ 10.1016/j.emj.2019.03.004

Hermawan, A. (2014). Penelitian bisnis: Paradigma kuantitatif. Grasindo.

Ihsanuddin. (2019). Jokowi: Kuncinya, reformasi di bidang pendidikan dan pelatihan vokasi. Kompas.com. Retrieved from https://nasional.kompas.com/read/2019/05/16/15034381/ jokowi-kuncinya-reformasi-di-bidang-pendidikan-dan-pelatihan-vokasi

Jooste, J. L., Louw, L., von Leipzig, K., Conradie, P. D. F., Asekun, O. O., Lucke, D., \& Hagedorn-Hansen, D. (2020). Teaching maintenance plan development in a learning factory environment. Procedia Manufacturing, 45, 379-385. https://doi.org/ 10.1016/j.promfg.2020. 04.040 
Kyvik, S., \& Reymert, I. (2017). Research collaboration in groups and networks: Differences across academic fields. Scientometrics, 113(2), 951-967. https://doi.org/10.1007/s11192017-2497-5

Mann, G., Bishop, T. U., Kaiser, K., \& Cafer, A., (2020) College2Youth: Design of multidisciplinary interdisciplinary undergraduate research experience. Journal of Nutrition Education and Behavior, 52(4), 447-450. https://doi.org/10.1016/j.jneb.2019.07.009

Mavrikios, D., Georgoulias, K., \& Chryssolouris, G. (2018). The Teaching Factory Paradigm: Developments and outlook. Procedia Manufacturing, 23, 1-6. https://doi.org/10.1016/j. promfg.2018.04.029

Mavrikios, D., Georgoulias, K., \& Chryssolouris, G. (2019). The Teaching Factory Network: A new collaborative paradigm for manufacturing education. Procedia Manufacturing, 31, 398403. https://doi.org/10.1016/j.promfg.2019.03.062

National Academies. (2005). Facilitating interdisciplinary research. National Academies Press.

Sackey, S. M., Bester, A., \& Adams, D. (2017). Industry 4.0 learning factory didactic design parameters for industrial engineering education in South Africa. South African Journal of Industrial Engineering, 28(1), 114-124. https://doi.org/10.7166/28-1-1584

Shamim, S., Cang, S., Yu, H., \& Li, Y. (2017). Examining the feasibilities of Industry 4.0 for the hospitality sector with the lens of management practice. Energies, 10(4). https://doi.org/ 10.3390/en10040499

Soto, J. C., Graf, N. B., \& Bravo, H. C. (2013). Profile of multidisciplinary group and collaborative style in interdisciplinary research. Procedia - Social and Behavioral Sciences, 106, 21442154. https:/doi.org/10.1016/j.sbspro.2013.12.245

Sudira, P. (2017). TVET abad XXI: Filosofi, teori, konsep dan strategi pembelajaran vokasional ( $2^{\text {nd }}$ ed.). In Hartono (Ed.). UNY Press.

Triyono, M. B. (2017). Tantangan revolusi industri ke-4 bagi pendidikan vokasi. Seminar Nasional Vokasi Dan Teknologi (SEMNASVOKTEK), 4, 1-5. Retrieved from https://eproceeding. undiksha.ac.id/index.php/semnasvoktek/article/view/653/495

Zuo, Z., \& Zhao, K., (2018) The more multidisciplinary the better? - The prevalence and interdisciplinarity of research collaboration in multidsciplinary institution. Journal of Infometrics, 12(3), 736-756. https://doi.org/10.1016/j.joi.2018.06.006 